\title{
Evidence for widespread creep on the flanks of the Sea of Marmara transform basin from marine geophysical data
}

\author{
D.J. Shillington ${ }^{1 *}$, L. Seeber ${ }^{1}$, C.C. Sorlien², M.S. Steckler ${ }^{1}$, H. Kurt ${ }^{3}$, D. Dondurur ${ }^{4}$, G. Çifçi, C. İmren ${ }^{3}$, M.-H. Cormier ${ }^{5}$, \\ C.M.G. McHugh ${ }^{1}$, S. Gürçay ${ }^{4}$, D. Poyraz ${ }^{3}$, S. Okay ${ }^{4}$, O. Atgın", and J.B. Diebold ${ }^{1}$ \\ 'Lamont-Doherty Earth Observatory of Columbia University, Palisades, New York 10964, USA \\ Earth Research Institute, University of California, Santa Barbara, California 93106, USA \\ ${ }^{3}$ Istanbul Technical University, Faculty of Mines, Department of Geophysical Engineering, Maslak TR-34469, Istanbul, Turkey \\ ${ }^{4}$ Dokuz Eylül University, Institute of Marine Sciences and Technology, Izmir, Turkey \\ 5University of Missouri, Department of Geological Sciences, Columbia, Missouri 65211, USA
}

\begin{abstract}
"Wave" fields have long been recognized in marine sediments on the flanks of basins and oceans in both tectonically active and inactive environments. The origin of "waves" (hereafter called undulations) is controversial; competing models ascribe them to depositional processes, gravity-driven downslope creep or collapse, and/or tectonic shortening. Here we analyze pervasive undulation fields identified in swath bathymetry and new high-resolution multichannel seismic (MCS) reflection data from the Sea of Marmara, Turkey. Although they exhibit some of the classical features of sediment waves, the following distinctive characteristics exclude a purely depositional origin: (1) parallelism between the crests of the undulations and bathymetric contours over a wide range of orientations, (2) steep flanks of the undulations (up to $\sim 40^{\circ}$ ), and (3) increases in undulations amplitude with depth. We argue that the undulations are folds formed by gravity-driven downslope creep that have been augmented by depositional processes. These creep folds develop over long time periods $(\geq 0.5 \mathrm{~m} . \mathrm{y}$.) and stand in contrast to geologically instantaneous collapse. Stratigraphic growth on the upslope limbs indicates that deposition contributes to the formation and upslope migration of the folds. The temporal and spatial evolution of the creep folds is clearly related to rapid tilting in this tectonically active transform basin.
\end{abstract}

\section{INTRODUCTION}

Undulations are common in marine sediments in diverse settings (e.g., Flood et al., 1993; Gardner et al., 1999; Lee et al., 2002), but their origin remains controversial. They have been attributed to a spectrum of sedimentary, tectonic, and/or gravitational processes, which themselves are functions of sedimentation rate, supply, and lithology, as well as slope gradient, the presence of fluids, sea-level change, bottom currents, and tectonics. Correctly pinpointing the origin of undulations is essential for unraveling the oceanographic, sedimentary, and tectonic evolution of basins and margins and for assessing geohazards related to slope stability.

Sediment waves can be created by turbidity currents and/or bottom currents (see Wynn and Stow, 2002, for a review). Turbidite flows generate waves on slopes $<\sim 1^{\circ}$ whose crests generally parallel bathymetric contours; they are usually tied to discrete regions of sediment input. Bottom currents generate waves oriented orthogonally to currents in regions of flat topography or at angles oblique to both the current direction and slope when formed in regions with bathymetric relief (e.g., Flood et al., 1993). Waves from both mechanisms have wavelengths of hundreds to thousands of meters, and heights of tens to hundreds of meters (Wynn and Stow, 2002). Beds are often thicker and coarser-grained

*E-mail: djs@1deo.columbia.edu. on the upslope/upcurrent limbs of waves, such that they appear to migrate upslope/upcurrent (Wynn and Stow, 2002; Berndt et al., 2006). Other characteristics include (1) continuity of reflections (i.e., no faults) between waves (Lee et al., 2002), (2) lack of tilting following deposition (Schwehr et al., 2007), and (3) the inability to palinspastically reconstruct waves (Holbrook et al., 2002).

Gravity-driven downslope collapse or creep is an alternative mechanism for explaining the undulations (Gardner et al., 1999; Lee and Chough, 2001). Here we define creep as slow gravity-driven downslope motion and deformation. Sediments deposited on slopes can become unstable depending on the slope angle, sedimentation rate and lithology, pore-pressure profile, or other interrelated factors (Sultan et al., 2004). Previous studies suggest that downslope motion occurs by the development of shear planes along or across stratigraphic boundaries (Gardner et al., 1999) and can occur by either geologically instantaneous slumping, creep, or a combination thereof (Lee and Chough, 2001).

Here we combine constraints on the orientation and spatial distribution of undulations in the Sea of Marmara, Turkey, from swath bathymetry data (Rangin et al., 2001) with constraints on their internal structure and temporal development from new multichannel seismic (MCS) data to decipher the processes that contributed to their formation and evolution.

\section{TECTONICS AND STRATIGRAPHY IN MARMARA}

The 150-km-long North Anatolian continental transform fault accounts for the westward motion of the Anatolian platelet relative to Eurasia at $25 \mathrm{~mm} / \mathrm{yr}$ (Reilinger et al., 2006). This motion is primarily accommodated by recurrent large earthquakes that absorb meters of slip over tens to hundreds of kilometers of the fault (Ambraseys and Finkel, 1995). The Sea of Marmara is a tectonically active basin along the North Anatolian fault where it splinters into multiple strands in northwestern Turkey (Fig. 1A). This trough comprises three main basins (west to east: Tekirdağ, Central, and Çınarcık basins), with water depths up to $1300 \mathrm{~m}$, separated by intrabasinal basement ridges (the Central and Western Highs) (Fig. 1A). Stratigraphy demonstrates that basin deepening is outpacing sedimentation, and that tilting of the margins of the basin and the intrabasinal submarine ridges is ongoing (e.g., Seeber et al., 2006).

Fresh submarine scarps, folds, recent landslides, and other shallow structures in Marmara attest to the interplay of active tectonic and sedimentary processes (e.g., Armijo et al., 2005). The 1999 earthquake triggered rapid mass movements and gas/fluid release and/or remobilization in the Gulf of Izmit (Kuşçu et al., 2005; Cormier et al., 2006). Catastrophic slope failure also occurs elsewhere in Marmara (e.g., in east Çınarcık and west Tekirdağ basins; Gazioğlu et al., 2005) (Fig. 1B), particularly in areas where subsidence and uplift are most rapid (e.g., Seeber et al., 2004). Slides comprise tilted blocks above clear décollements and headwalls with dips $>\sim 15^{\circ}$.

\section{DATA ACQUISITION AND PROCESSING}

The Turkish-American Marmara Multichannel (TAMAM) project acquired $>3000 \mathrm{~km}$ of high-resolution MCS reflection and chirp data in July 2008 and June 2010 aboard the R/V K. Piri Reis, which is operated by Dokuz Eylül University (Izmir, Turkey) (Fig. 1A). MCS data were acquired on a $450 \mathrm{~m}$ streamer in 2008 , and on a $700 \mathrm{~m}$ or $1500 \mathrm{~m}$ streamer in 2010. The common midpoint (CMP) spacing was $3.125 \mathrm{~m}$, streamer depth was $3-4 \mathrm{~m}$, and 


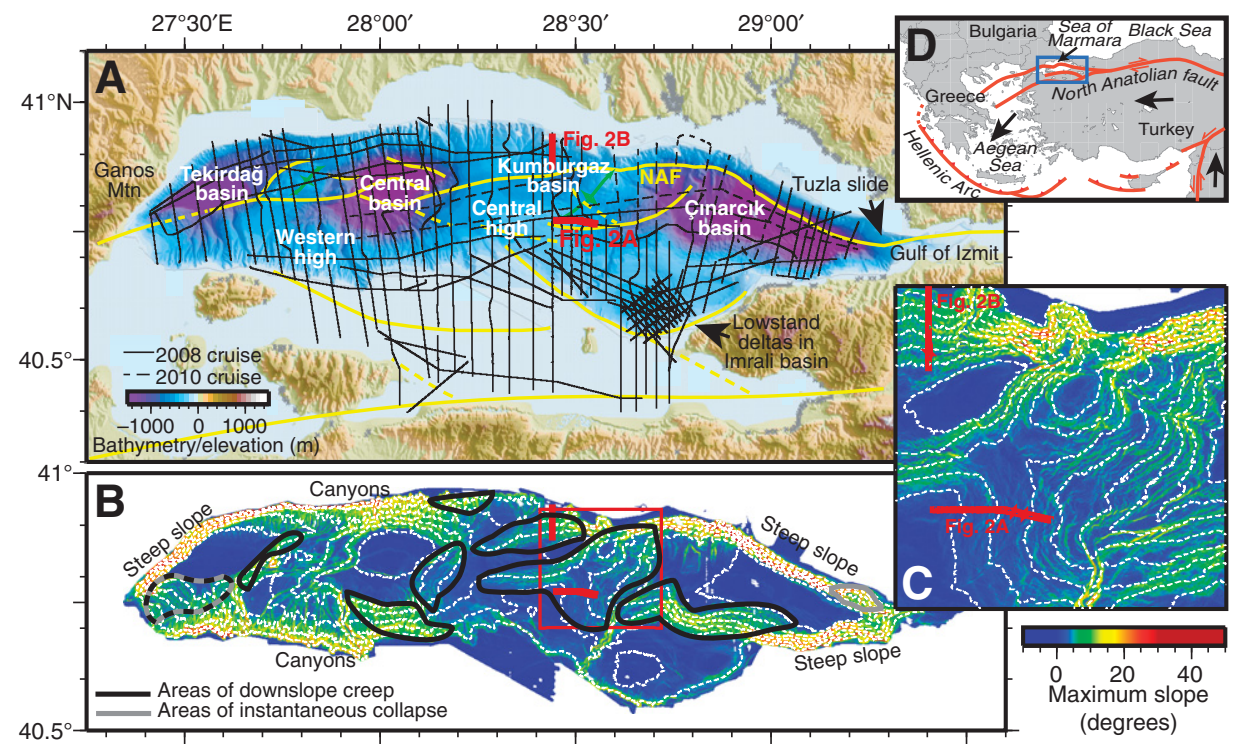

Figure 1. A: Bathymetry (Rangin et al., 2001) and elevation with Turkish-American Marmara Multichannel (TAMAM) project multichannel seismic lines. Yellow/green lines indicate major faults. NAF-North Anatolian fault. B: Maximum slope from bathymetry with contour interval of $200 \mathrm{~m}$. Lines of higher slope paralleling bathymetric contours are surface expression of undulations. Black lines indicate areas of creep. Gray lines indicate areas of instantaneous collapse. Gray-black dashed area in Tekirdağ basin marks region where possible creep folds overlie an area of previous collapse. C: Close-up of Central High (red box in B) with contour interval of 50 m. D: Regional context for Sea of Marmara (after Reilinger et al., 2006).

the sample rate was $1 \mathrm{~ms}$. The source was a $45 / 45$ in $^{3}$ generator injector (GI) air gun fired every 12.5 or $18.75 \mathrm{~m}$. Ship traffic required several track deviations. Processing steps included minimum-phase band-pass filtering at 12-200 Hz, dense velocity analyses, stacking, and FK or Kirchhoff migration using smoothed stacking velocities.

\section{OBSERVATIONS}

Bathymetry and MCS data reveal a spectrum of features in the shallow sediments $(\sim 1 \mathrm{~km})$, including two classes of undulations on the basin margins and the flanks of basement highs (Figs. 1B and 2; see the GSA Data Repository ${ }^{1}$ ). One set is clearly formed by geologically instantaneous slope failure (see Fig. DR6 in the Data Repository). The second class is characterized by gradual long-term development and is the focus of this study.

The dominant wavelength of most features is $\sim 0.5-1 \mathrm{~km}$, although they range from as small as $\sim 0.2 \mathrm{~km}$ to as large as $\sim 1.5-2 \mathrm{~km}$. They are often asymmetric, with downslope limbs steeper than upslope limbs and compressed sedimentary sections on the downslope limbs. Undula-

${ }^{1}$ GSA Data Repository item 2012127, Figures DR1-DR7, supplementary images of creep folds and collapse structures in seismic and bathymetric data, is available online at www.geosociety.org/pubs /ft2012.htm, or on request from editing@geosociety .org or Documents Secretary, GSA, P.O. Box 9140, Boulder, CO 80301, USA. tion amplitude usually increases with depth in the upper sedimentary section from $\sim 20$ m near the seafloor to up to $\sim 150-200 \mathrm{~m}$ at depth. Correspondingly, the dips of the limbs also increase with depth from $\sim 5^{\circ}-10^{\circ}$ near the seafloor to as high as $\sim 30^{\circ}-40^{\circ}$ at depth (Fig. 2).
Individual undulations appear to be separated by shear surfaces on some profiles (Fig. 2B inset), although elsewhere, horizons can be traced continuously between features (Fig. 2A inset). Shear surfaces appear to form along tilted stratigraphic layers and have typical dips of $\sim 30^{\circ}-40^{\circ}$. In most cases, a sharp basal decoupling surface is not observed.

The upslope limbs exhibit larger bed thickness and fanning of strata, indicating that tilt and accommodation space grow at the rate that sediment accumulates. Undulations grew for $>0.5$ m.y., according to the internal stratigraphy of the undulations and an age model based on a stack of lowstand deltas in Imrali basin (Figs. 1A and 2A) (Sorlien et al., 2012). Stratigraphic growth within the youngest sediments on some undulations demonstrates that they continue to be active, while a drape on others implies they may be inactive.

Domains with active undulations are spectacularly revealed in maps of maximum seafloor slope, where they manifest as anastomosing lines of relatively high slope (Figs. 1B and $1 \mathrm{C}$; see the Data Repository figures). Active undulations are identified in Marmara in nearly every sedimented region with a slope of $\sim 3^{\circ}-$ $10^{\circ}$ (Fig. 1B; see the Data Repository figures). Undulations have a wide range of orientations and commonly exhibit relatively sharp changes in strike (Fig. 1C). Highly variable orientations correlate directly with bathymetric contours. Undulations are conspicuously missing from areas with well-developed canyons or on slopes $<3^{\circ}$ or $>10^{\circ}$ (Fig. 1B).

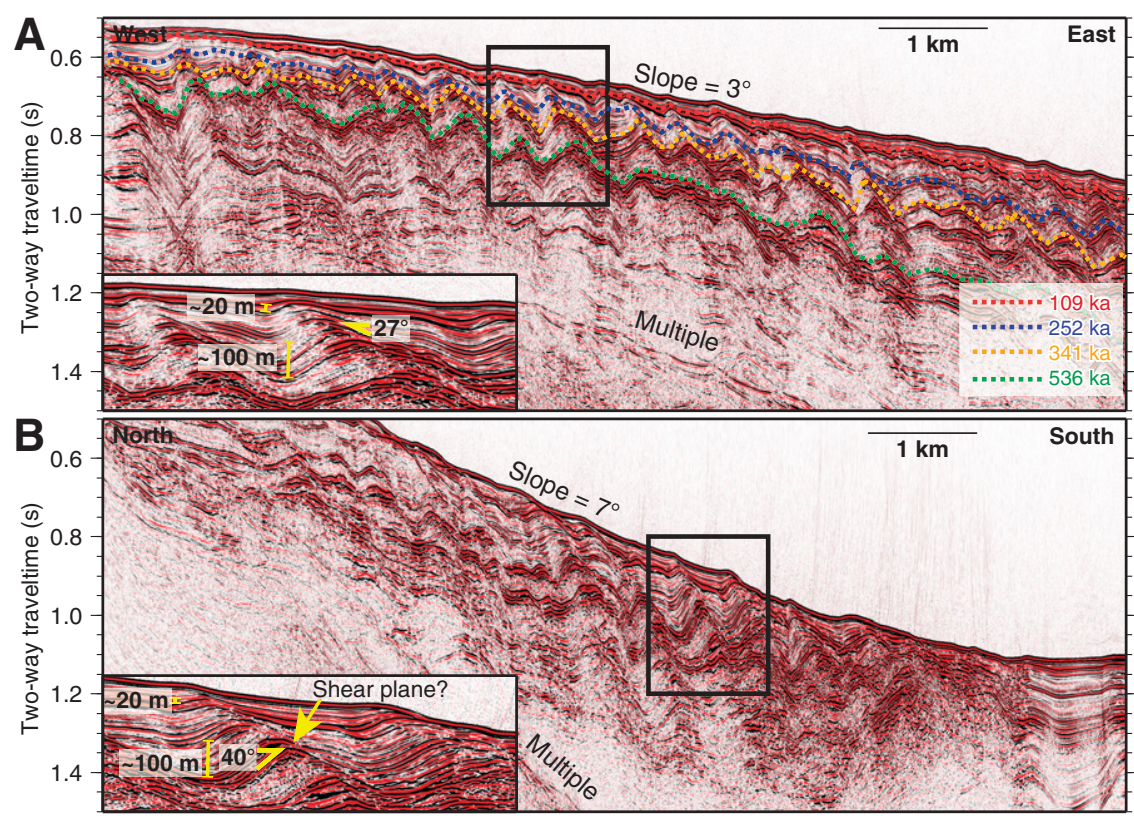

Figure 2. Multichannel seismic profiles with creep folds. Locations in Figure 1. Vertical exaggeration is $\sim 4: 1$ (assuming $1800 \mathrm{~m} / \mathrm{s}$ ). Insets at $\sim 1: 1$. Note steep fold limb dips $\left(\sim 20^{\circ}-40^{\circ}\right)$ and increases in amplitude with depth. A: Central High. Note continuity of reflections between folds. Colored dashed lines show minimum age model of Sorlien et al. (2012). B: North of Kumburgaz basin. Note apparent shear planes between folds. 


\section{INTERPRETATION AND DISCUSSION}

Undulations were recognized in the sediments of the Sea of Marmara from older, lowerresolution data sets, and interpreted either as compressional folds (e.g., Okay et al., 1999) or as sedimentary features formed from bottom currents (e.g., İmren et al., 2001). Here we argue that gravity-driven downslope creep augmented by sedimentation best explains the formation of these features.

The diversity of orientations of the undulations, their parallelism with bathymetric contours, and the absence of a systematic relationship to features in any structural model clearly excludes tectonic shortening as an explanation.

A purely depositional origin can also be excluded by the characteristics of the undulations and by the oceanography in the Sea of Marmara. Where currents interact with seafloor topography, sediment waves are expected to be oblique to bathymetric contours and current direction (Flood et al., 1993), and this is not observed; they consistently parallel bathymetric contours throughout the basin. Their locations are also not related to any particular sediment source, as would be expected for turbidity current waves (e.g., Wynn and Stow, 2002). Although the wavelengths of the Marmara undulations are similar to those of sediment waves, the dips between and within these features are significantly steeper $\left(\sim 30^{\circ}-40^{\circ}\right)$ than those for well-studied sediment waves, which are typically $2^{\circ}-8^{\circ}$ (Gardner et al., 1999; Berndt et al., 2006). Finally, the observed increases in undulation amplitude with depth are difficult to explain by deposition alone. Further rotation and/or steepening of sediment layers should not occur following deposition if they are sedimentary features (Schwehr et al., 2007).

Furthermore, bottom currents in the Sea of Marmara may be too weak to promote sediment waves by deposition alone. Two-layer flow is driven by low-salinity (20\%) water coming from the Black Sea via the Bosphorus strait, and by denser saline ( $\sim 39 \%$ o) water of the Mediterranean coming via the Dardanelles strait, resulting in a dominant west-to-east bottom current (Beşiktepe et al., 1994). Incoming Mediterranean waters are generally warmer and lighter than water in the deep basins of Marmara (1300 m), and they thus intrude the water around the pycnocline ( $25 \mathrm{~m})$ (Beşiktepe et al., 1994). Deep water is only formed during the winter. Bottom currents are also modulated by basement topography. For both of these reasons, bottom currents are sluggish, particularly in eastern Marmara $(<0.05 \mathrm{~m} / \mathrm{s})$ (Beşiktepe et al., 1994). Low concentrations of dissolved oxygen in sediments from the deep basins provide additional evidence for low circulation. Together, the characteristics of the undulations and the oceanography of Marmara exclude a purely depositional origin.
We propose that downslope creep is the dominant process controlling the formation of undulations, which we term creep folds (Fig. 3). The steep dips of fold limbs are consistent with a deformational origin. Increases in fold amplitude with depth could be the consequence of continued creep in an area of ongoing sedimentation, where deeper older sediments experience more cumulative folding.

The fact that some folds appear to be separated by shear planes while others are not (Fig. 2) indicates that a spectrum of deformational styles accommodate creep. Folding accommodates deformation until failure occurs parallel to bedding planes (Fig. 3D). Folding may also involve thickening and thinning of sedimentary layers themselves by extension and contraction (Figs. 2 and $3 \mathrm{~B}$ ). In some regions of creep, the mode of deformation changes from folding to faulting along strike (e.g., southern Çınarcık basin; see the Data Repository figures). Additionally, it is likely that shear is more prevalent than can be identified in seismic sections since it will occur preferentially along bedding planes, and offsets may frequently be small.

Even though downslope creep is the dominant process forming the Marmara folds, stratigraphic growth on their upslope flanks implies that deposition also enhances their evolution. The subtle seafloor ridges created by creep folding modulate sedimentation, enhancing deposition on the upslope flanks (Fig. 3). Sedimentation rate is high enough and downslope creep is slow enough that fold evolution is recorded as stratigraphic growth.

Creep is likely controlled by slope and the strength of the sediment, which can be strongly influenced by pore-fluid pressure (e.g., Gardner et al., 1999). High rates of fine-grained sedimentation can promote undercompaction and pore-fluid overpressure in marine sediments (e.g., Swarbrick and Osborne, 1998); overpressure is common in many basins and continental margins, even at shallow burial depths (hundreds of meters) (Gordon and Flemings, 1998). Elevated pore pressure reduces the effective stress and could result in weak intervals within the sedimentary section along which downslope failure could more readily occur (Figs. 3A and $3 \mathrm{~B})$. The pore-pressure profile is expected to change through time and over small distances $(\sim 1 \mathrm{~km})$ in response to variations in sedimentation rate and lithology, deformation, compaction, and fluid escape (Fig. 3C) (e.g., Gordon and Flemings, 1998). As a result, the strength profile will also change through time, such that a single dominant decoupling surface may never develop, and the size and geometry of folds can thus vary through the section.

Variations in pore-fluid content and sediment lithology may also promote instability. Studies focused on the North Anatolian fault have

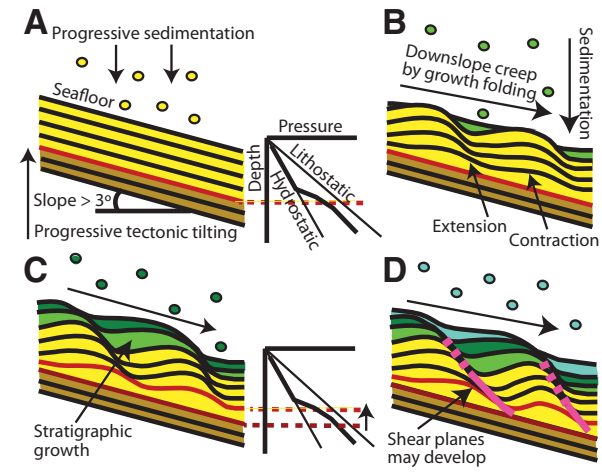

Figure 3. Conceptual model for creep folds. A: Rapid sedimentation leads to elevated pore pressures and weak regions within sediment pile (red line). Combined with tectonic tilting, this creates instability. B: Downslope creep occurs by folding above weak interval. Deposition is modulated by deformation of seafloor. C: Ongoing sedimentation, tilting, and deformation cause evolution of porepressure regime and strength profile of sediments. D: Shear planes may develop along bedding planes between folds.

documented the presence of thermogenic and biogenic gas in Marmara sediments (Géli et al., 2008). The Sea of Marmara has experienced periods of isolation and other dramatic paleoceanographic variations, which could result in variations in sediment lithology (Çağatay et al., 2000). Finally, submarine creep may be triggered by earthquakes, as is observed for catastrophic landslides (Sultan et al., 2004) and onshore creep (Sleep, 2011).

The recognition of widespread creep in the Sea of Marmara is significant regionally and globally. Many transform and extensional basins are underfilled in their early stages when sediment supply cannot keep up with a rapidly expanding basin (e.g., Schlische and Olsen, 1990). Slow downslope creep and folding owing to ongoing tectonic tilting and sedimentation may be common in such situations. Correctly identifying these undulations as creep folds (rather than sediment waves or tectonic deformation) is essential for understanding the tectonic and oceanographic evolution of these settings.

The orientation and slope of the flanks of the Sea of Marmara and other active basins are controlled by tectonics; thus, the creep folds provide a record of tectonic evolution. In several areas in Marmara, folds vary through the section in wavelength, amplitude, orientation, and the time span over which they were active. This evolution offers constraints on the chronology of rotation and tilting. Creep folds are also offset by active faults, providing a reference point for reconstructing fault offsets. Similar features recognized in other basins and margins might also have the potential to provide novel constraints on tectonics (e.g., Adriatic Sea [Cattaneo et al., 
2004] and in active basins in the western Pacific [Lee and Chough, 2001]).

The loss of gravitational potential in the Sea of Marmara and elsewhere by creep may also diminish hazards associated with catastrophic collapse.

\section{CONCLUSIONS}

Swath bathymetry and new high-resolution MCS data reveal widespread undulations in sediments within the Sea of Marmara. They occur on every sedimented region with a slope of $\sim 3^{\circ}-10^{\circ}$ except those cut by canyons. Remarkable parallelism of undulation crests with bathymetric contours, steep dips of fold limbs, increasing amplitudes of the folds with depth, and slow long-term growth ( $>0.5 \mathrm{~m}$.y.) point to downslope creep as the dominant mechanism for their formation. Creep is augmented by deposition. This combination of collapse and deposition may be common globally. Distinguishing between different mechanisms for the growth and evolution of features in marine sediments is important for understanding the tectonic and oceanographic evolution of basins and margins as well as assessing geohazards associated with slope stability in these settings.

\section{ACKNOWLEDGMENTS}

This project was supported by U.S. National Science Foundation grants OCE-0328119 and OCE0928447 to Lamont-Doherty Earth Observatory (LDEO) and OCE-0327273 and OCE-0929063 to the University of California-Santa Barbara, by LDEO, and by Dokuz Eylül University (Turkey). The Scientific and Technological Research Council of Turkey (TUBITAK)-BIDEB supported a six-month research visit for Kurt to LDEO and the University of Missouri. We thank the captains and crew of the R/V K. Piri Reis, who made the acquisition of these data possible despite challenging conditions. We thank Hydroscience Technologies Inc. for supporting the seismic systems of R/V K. Piri Reis, Landmark for ProMAX software, and Seismic Micro Technology for Kingdom Suite software. H. Carton, S. Singh, M. Laigle, A. Bécel, A. Hirn, and others generously made data available from previous programs in Marmara. Reviews by Sandra Wyld, Christian Berndt, and three anonymous reviewers greatly improved the paper.

\section{REFERENCES CITED}

Ambraseys, N.N., and Finkel, C.F., 1995, The seismicity of Turkey and adjacent areas-A historical review, 1500-1800: Istanbul, EREN, $240 \mathrm{p}$.

Armijo, R., and 22 others, 2005, Submarine fault scarps in the Sea of Marmara pull-apart (North Anatolian Fault): Implications for seismic hazard in Istanbul: Geochemistry Geophysics Geosystems, v. 6, Q06009, doi:10.1029/2004GC000896.

Berndt, C., Cattaneo, A., Szuman, M., Trincardi, F., and Masson, D., 2006, Sedimentary structures offshore Ortona, Adriatic Sea-Deformation or sediment waves?: Marine Geology, v. 234, p. 261-270, doi:10.1016/j.margeo.2006.09.016.

Beşiktepe, Ş.T., Sur, H., Özsoy, E., Latif, M.A., Oğuz, T., and Ünlüata, Ü., 1994, The circulation and hydrography of the Marmara Sea: Progress in Oceanography, v. 34, p. 285-334, doi:10.1016 /0079-6611(94)90018-3.
Çağatay, M.N., Görür, N., Algan, O., Eastoe, C., Tchapalyga, A., Ongan, D., Kuhn, T., and Kuşcu, I., 2000, Late Glacial-Holocene palaeoceanography of the Sea of Marmara: Timing of connections with the Mediterranean and the Black Seas: Marine Geology, v. 167, p. 191-206, doi:10.1016 /S0025-3227(00)00031-1.

Cattaneo, A., Correggiari, A., Marsset, T., Thomas, Y., Marsset, B., and Trincardi, F., 2004, Seafloor undulation pattern on the Adriatic shelf and comparison to deep-water sediment waves: Marine Geology, v. 213, p. 121-148, doi:10.1016/j margeo.2004.10.004.

Cormier, M.-H., Seeber, L., McHugh, C.M.G., Polonia, A., Çagatay, N., Emre, Ö., Gasperini, L., Görür, N., Bortoluzzi, G., Bonatti, E., Ryan, W.B.F., Newman, K.R., 2006, North Anatolian Fault in the Gulf of Izmit (Turkey): Rapid vertical motion in response to minor bends of a nonvertical continental transform: Journal of Geophysical Research, v. 111, B04102, doi:10.1029 /2005JB003633.

Flood, R.D., Shor, A.N., and Manley, P.L., 1993, Morphology of abyssal mudwaves at project MUDWAVES sites in the Argentine Basin: Deep-Sea Research Part II: Topical Studies in Oceanography, v. 40, p. 859-888, doi:10.1016/0967-0645 (93)90038-O

Gardner, J.V., Prior, D.B., and Field, M.E., 1999, Humboldt Slide-A large shear-dominated retrogressive slope failure: Marine Geology, v. 154 , p. $323-338$, doi:10.1016/S0025-3227 (98)00121-2.

Gazioğlu, C., Yücel, Z.Y., and Doğan, E., 2005, Morphological features of major submarine landslides of Marmara Sea using multibeam data: Journal of Coastal Research, v. 214, p. 664673, doi:10.2112/03-0060.1

Géli, L., and 17 others, 2008, Gas emissions and active tectonics within the submerged section of the North Anatolian Fault zone in the Sea of Marmara: Earth and Planetary Science Letters, v. 274, p. 34-39, doi:10.1016/j.eps1.2008.06.047.

Gordon, D.S., and Flemings, P.B., 1998, Generation of overpressure and compaction-driven fluid flow in Plio-Pleistocene growth-faulted basin, Eugene Island 330, offshore Louisiana: Basin Research, v. 10, p. 177-196, doi:10.1046/j.1365 -2117.1998.00052.x.

Holbrook, W.S., Lizarralde, D., Pecher, I.A., Gorman, A.R., Hackwith, K.L., Hornbach, M., and Saffer, D., 2002, Escape of methane gas through sediment waves in a large methane hydrate province: Geology, v. 30, p. 467-470, doi: 10.1130 /0091-7613(2002)030<0467:EOMGTS > 2.0 . $\mathrm{CO} ; 2$.

İmren, C., Le Pichon, X., Rangin, C., Demirbag, E., Ecevitoglu, B., and Görür, N., 2001, The North Anatolian Fault within the Sea of Marmara: A new interpretation based on multi-channel seismic and multi-beam bathymetry: Earth and Planetary Science Letters, v. 186, p. 143-158, doi:10.1016/S0012-821X(01)00241-2.

Kuşçu, İ., Okamura, M., Matsuoka, H., Gökaşan, E., Awata, Y., Tur, H., Şimşek, M., and Keçer, M., 2005, Seafloor gas seeps and sediment failures triggered by the August 17, 1999 earthquake in the Eastern part of the Gulf of İzmit, Sea of Marmara, NW Turkey: Marine Geology, v. 215, p. 193-214, doi:10.1016/j.margeo.2004.12.002.

Lee, H.J., Syvitski, J.P.M., Parker, G., Orange, D., Locat, J., Hutton, E.W.H., and Imran, J., 2002, Distinguishing sediment waves from slope failure deposits: Field examples, including the 'Humboldt slide', and modelling results: Marine
Geology, v. 192, p. 79-104, doi:10.1016/S0025 -3227(02)00550-9.

Lee, S.H., and Chough, S.K., 2001, High-resolution $(2-7 \mathrm{kHz})$ acoustic and geometric characters of submarine creep deposits in the South Korea Plateau, East Sea: Sedimentology, v. 48, p. 629644, doi:10.1046/j.1365-3091.2001.00383.x

Okay, A.I., Demirbag, E., Kurt, H., Okay, N., and Kuscu, I., 1999, An active, deep marine strikeslip basin along the North Anatolian fault in Turkey: Tectonics, v. 18, p. 129-147, doi:10.1029 /1998TC900017.

Rangin, C., İmren, C., Crusson, A., Normand, A., Le Drezen, E., and Le Bot, A., 2001, Marine atlas of the Sea of Marmara (Turkey): Brest, France, IFREMER (French Research Institute for Exploration of the Sea).

Reilinger, R., and 24 others, 2006, GPS constraints on continental deformation in the AfricaArabia-Eurasia continental collision zone and implications for the dynamics of plate interactions: Journal of Geophysical Research, v. 111, B05411, doi:10.1029/2005JB004051.

Schlische, R.W., and Olsen, P.E., 1990, Quantitative filling model for continental extensional basins with applications to early Mesozoic rifts of eastern North America: Journal of Geology, v. 98, p. 135-155, doi:10.1086/629390.

Schwehr, K., Driscoll, N., and Tauxe, L., 2007, Origin of continental margin morphology: Submarineslide or downslope current-controlled bedforms, a rock magnetic approach: Marine Geology, v. 240, p. 19-41, doi:10.1016/j.margeo.2007.01.012.

Seeber, L., Emre, O., Cormier, M.-H., Sorlien, C.C., McHugh, C.M.G., Polonia, A., Ozer, N., and Cagatay, N., 2004, Uplift and subsidence from oblique slip: The Ganos-Marmara bend and the North Anatolian Transform, western Turkey: Tectonophysics, v. 391, p. 239-258, doi:10.1016 /j.tecto.2004.07.015.

Seeber, L., Cormier, M.-H., McHugh, C., Emre, O., Polonia, A., and Sorlien, C., 2006, Rapid subsidence and sedimentation from oblique slip near a bend on the North Anatolian transform fault in the Marmara Sea, Turkey: Geology, v. 34, p. 933-936, doi:10.1130/G22520A.1.

Sleep, N.H., 2011, Deep-seated downslope slip during strong seismic shaking: Geochemistry Geophysics Geosystems, v. 12, Q12001, doi:10.1029 /2011GC003838.

Sorlien, C.C., and 14 others, 2012, Uniform basin growth over the last $500 \mathrm{ka}$, North Anatolian Fault, Marmara Sea, Turkey: Tectonophysics, doi:10.1016/j.tecto.2011.10.006 (in press).

Sultan, N., and 12 others, 2004, Triggering mechanisms of slope instability processes and sediment failures on continental margins: A geotechnical approach: Marine Geology, v. 213, p. 291-321, doi:10.1016/j.margeo.2004.10.011.

Swarbrick, R.E., and Osborne, M.J., 1998, Mechanisms that generate abnormal pressures: An overview, in Law, B.E., et al., eds., Abnormal pressures in hydrocarbon environments: American Association of Petroleum Geologists Memoir 70, p. 13-34.

Wynn, R.B., and Stow, D.V., 2002, Classification and characterisation of deep-water sediment waves: Marine Geology, v. 192, p. 7-22, doi:10.1016/ S0025-3227(02)00547-9.

Manuscript received 16 July 2011

Revised manuscript received 8 December 2011 Manuscript accepted 16 December 2011

Printed in USA 